\title{
The prognostic impact of microRNA sequence polymorphisms on the recurrence of patients with completely resected non-small cell lung cancer
}

Kyong-Ah Yoon, PhD, ${ }^{a}$ Hyekyoung Yoon, MS, ${ }^{\text {a }}$ Sohee Park, $\mathrm{PhD},{ }^{\mathrm{b}}$ Hee-Jin Jang, MD, Jae Ill Zo, MD, PhD, ${ }^{\mathrm{a}, \mathrm{c}}$ Hyun-Sung Lee, MD, PhD, ${ }^{\mathrm{a}, \mathrm{c}}$ and Jin Soo Lee, MD, PhD ${ }^{\mathrm{a}, \mathrm{c}}$

Objectives: MicroRNAs (miRNAs) are widely known for their function as regulators of gene expression via translational repression. Polymorphisms in miRNAs have been shown to affect the regulatory capacity of miRNAs by influencing miRNA processing and/or miRNA-mRNA interactions. The purpose of this study was to investigate the association between 7 single nucleotide polymorphisms (SNPs) commonly found in precursor miRNA (pre-miRNA) and primary miRNA (pri-miRNA) sequences and the recurrence of disease in patients who underwent a complete resection of non-small cell lung cancer (NSCLC).

Methods: Five SNPs found in pre-miRNAs (rs11614913/miR-196a2, rs2910164/miR-146a, rs6505162/miR423, rs2289030/miR-492, and rs895819/miR-27a) and 2 SNPs found in pri-miRNAs (rs7372209/miR-26a-1 and rs213210/miR-219-1) were genotyped in 388 patients with NSCLC.

Results: Among 388 patients, variants of the rs2910164 SNP were significantly associated with recurrence-free survival (RFS) $(P=.016, \log$-rank test). When the results were subdivided by the tumor stage, variants of the rs2910164 and rs11614913 SNPs positively correlated with a better RFS (adjusted hazard ratio [HR], 0.48; 95\% confidence interval [CI], 0.28-0.80; adjusted HR, $0.60 ; 95 \%$ CI, $0.38-0.94$, respectively) in patients with stage II and stage III disease. Moreover, RFS significantly improved in patients with higher numbers of variant alleles in the rs2910164 and rs11614913 SNPs.

Conclusions: Our findings suggest that polymorphisms in the rs2910164 of miR-146a and the rs11614913 of miR-196a2 are associated with prognosis in patients with completely resected NSCLC. (J Thorac Cardiovasc Surg 2012;144:794-807)

MicroRNAs (miRNA) are endogenous, small, noncoding RNAs that play important roles in the posttranscriptional regulation of messenger RNA (mRNA) expression. ${ }^{1,2}$ Mature miRNAs are generated from precursor miRNAs (pre-miRNAs), which are the processed products of the longer primary miRNA (pri-miRNA) transcripts. ${ }^{3,4}$ MicroRNAs regulate gene expression by translational inhibition or mRNA cleavage, and these mechanisms are dependent on complete or nearly complete sequence complementarity. ${ }^{2}$ Many studies have reported that the dysfunction of miRNAs that target oncogenic or tumor suppressor activity can influence cancer development. ${ }^{5-8}$ The potential roles of miRNAs in cancer cells have been

From the Lung Cancer Branch, Research Institute and Hospital, ${ }^{a}$ the National Cancer Control Research Institute, ${ }^{\mathrm{b}}$ and the Center for Lung Cancer, Research Institute and Hospital, ${ }^{\mathrm{c}}$ National Cancer Center, Goyang, Gyeonggi, Republic of Korea.

This work was supported by National Cancer Center Research Grant No. 1010040 and No.1110260.

Disclosures: Authors have nothing to disclose with regard to commercial support.

Received for publication Jan 14, 2012; revisions received May 12, 2012; accepted for publication June 12, 2012; available ahead of print July 23, 2012.

Address for reprints: Jin Soo Lee, MD, PhD or Hyun-Sung Lee, MD, PhD, Research Institute and Hospital, National Cancer Center, 323 Ilsan-ro, Ilsandong-gu, Goyang, Gyeonggi, 410-769, Korea (E-mail: jslee@ncc.re.kr or thoracic@ncc. re.kr).

0022-5223/\$36.00

Copyright (c) 2012 by The American Association for Thoracic Surgery

http://dx.doi.org/10.1016/j.jtcvs.2012.06.030 suggested by various reports that have characterized the cellular functions of miRNAs as well as by miRNA expression profiling in various cancers. For example, the first miRNA to be associated with lung cancer was let-7, and decreased let-7 expression was shown to lead to an increase in the expression level of its target RAS. ${ }^{9,10}$

Recently, several miRNA polymorphisms have been reported to modify the regulatory capacity of their respective miRNA by affecting miRNA processing and/or miRNAmRNA interactions. ${ }^{11,12}$ With respect to cancer, miRNA single nucleotide polymorphisms (SNPs) can be used as genetic markers to predict cancer susceptibility and prognosis. For example, the pri-miRNA SNP rs213210 found in miR-219-1 correlates with an increased risk for esophageal cancer, ${ }^{13}$ and the variants of the rs7372209 SNP found in miR-26a-1 have been associated with the prognosis for colon cancer. ${ }^{14}$ The SNPs rs 2289030 found in pre-miR-492 and the SNP rs6505162 found in premiR-423 have been correlated with an increased risk for bladder cancer in white subjects. ${ }^{15}$ The pre-miRNA SNP rs895819 found in pre-miR-27a has also been shown to be related to gastric cancer susceptibility and a reduced risk for familial breast cancer. $^{16,17}$ Two functional polymorphisms, rs11614913 in miR-196a2 and rs2910164 in miR-146a, also appear to contribute to the clinical 


$$
\begin{array}{ll}
\text { Abbreviations and Acronyms } \\
\text { CI } & =\text { confidence interval } \\
\text { HR } & =\text { hazard ratio } \\
\text { miRNA } & =\text { microRNA } \\
\text { mRNA } & =\text { messenger RNA } \\
\text { NSCLC } & =\text { non-small cell lung cancer } \\
\text { pre-miRNA } & =\text { precursor microRNA } \\
\text { pri-miRNA } & =\text { primary microRNA } \\
\text { RFS } & =\text { recurrence-free survival } \\
\text { SNP } & =\text { single nucleotide polymorphism }
\end{array}
$$

outcome of various cancers, suggesting that mature miRNAs have regulatory roles as well. ${ }^{17,18}$ To evaluate the association between miRNA polymorphisms and patient prognosis of non-small cell lung cancer (NSCLC), we evaluated whether 7 SNPs in various pre-miRNAs and pri-miRNAs could predict the clinical outcomes of patients who underwent complete resection for NSCLC.

\section{METHODS}

\section{Study Population}

This study included 388 patients who had undergone surgical resections for NSCLC at the National Cancer Center in Korea from 2001 to 2008, and follow-up information was available for every patient. The clinicopathologic characteristics of the patients with lung cancer are shown in Table 1 . We retrospectively reviewed the medical and pathology records for each patient. Chest computed tomography, positron emission tomography, bronchoscopy, and pulmonary function tests were performed preoperatively. Chest computed tomography scans were obtained postoperatively at 3-month intervals, and positron emission tomography-computed tomography scans were obtained annually to detect recurrence of the tumor. The patients were histologically diagnosed with pathologic stage I, II, or IIIA adenocarcinoma or squamous cell carcinoma after the pulmonary resection and complete lymph node dissection. Criteria for patient exclusion included patients who underwent a limited resection such as a wedge resection or segmentectomy and patients who underwent neoadjuvant chemotherapy treatment. The patients voluntarily donated blood for genetic tests after signing an informed consent form, which was previously approved by the institutional review board.

The recurrence-free survival (RFS) rate was calculated from the date of surgery to the date of recurrence or to the date of the last follow-up. Local recurrences were defined as lesions occurring within the resection margins such as bronchial stumps or staple lines. Regional recurrences were defined as lesions that occurred within the hilar or mediastinal lymph nodes, pleural cavity, or ipsilateral lung. Distant recurrences were defined as lesions occurring within the contralateral lung, brain, liver, adrenal glands, bone, or other locations.

\section{Selection and Genotyping of the miRNA \\ Polymorphisms}

The candidate miRNA polymorphisms were selected on the basis of a previously identified association with cancer risk or prognosis by conducting a literature review. ${ }^{10-19}$ The minor allele frequency was also considered during the selection of the target SNPs. Data from the International HapMap Project was used to select SNPs that have a minor allele frequency greater than $20 \%$ in Asians for our analysis. Five SNPs in pre-miRNAs (rs11614913/miR-196a2, rs2910164/miR-146a,
rs6505162/miR-423, rs2289030/miR-492, and rs895819/miR-27a) and 2 SNPs in pri-miRNAs (rs7372209/miR-26a-1 and rs213210/miR-219-1) fit the aforementioned criteria and were selected for genotyping analysis. Genomic DNA was extracted from the peripheral blood using the QIAamp DNA Blood Mini Kit (Qiagen, Valencia, Calif) according to the manufacturer's instructions. Genotyping was conducted with TaqMan probes using a 5'-nuclease assay (Applied Biosystems, Foster City, Calif). To confirm the reproducibility of our method, 50 samples were genotyped in duplicate, and all samples showed concordant results.

\section{Statistical Analysis}

Patients who currently smoked or who smoked more than 100 cigarettes during their lifetime were defined as ever-smokers. The Hardy-Weinberg equilibrium of each allele was calculated to ensure that the genotyping results were reliable. The correlation between miRNA polymorphisms and clinicopathologic characteristics was analyzed using the $\chi^{2}$ test. We analyzed the association between the miRNA polymorphisms and NSCLC prognosis with respect to the cancer stage. The RFS rates were assessed using the Kaplan-Meier product limit method, and the trend among the miRNA polymorphisms was estimated with the log-rank test. The hazard ratios (HRs) and the associated $95 \%$ confidence intervals (CIs) were derived from a Cox proportional-hazards regression model. The statistically significant $(P<.05)$ covariates from the log-rank test (age, gender, smoking status, histologic tumor type, stage, and postoperative complications) were further analyzed after adjustment in a multivariable Cox proportionalhazards regression model using RFS as the dependent variable. We also analyzed statistically significant polymorphisms that occurred in combination with other polymorphisms, and individuals were represented by categories for the number of variant alleles present in the polymorphisms studied. All of the reported $P$ values were 2-sided. Stata/SE version 11 (StataCorp LP, College Station, Tex) was used for all statistical analyses.

\section{RESULTS}

\section{Patient Characteristics}

Tumor recurrence was assessed in 388 patients who had undergone surgical resection of the lung and had clinical information available for review. The ever-smokers and patients with early-stage (stage IA/IB) cancer and adenocarcinoma were dominant in this group. We observed recurrence in 71 patients over a median follow-up period of 36.8 months. By univariate analysis, gender, smoking status, histology, and pathologic tumor stage were all significantly associated with the survival outcome $(\log -$ rank $P<.05)$ (Table 1). These factors and notable clinical factors such as age and postoperative complication were adjusted as covariates in a multivariate Cox regression analysis. Specifically, the patients with advanced-stage disease had a significantly poorer clinical outcome (HR, 3.56; 95\% CI, 2.21-5.74) when compared with the patients with stage I cancer. Adjuvant chemotherapy was not associated with RFS. The patients with lung squamous cell carcinoma had a higher risk of death than did those with adenocarcinoma (HR, 2.00; 95\% CI, 1.25-3.20).

\section{The Effects of miRNA Polymorphisms on Clinicopathologic Characteristics}

We conducted stratified and interaction analyses of 7 miRNA polymorphisms with the major clinicopathologic 
TABLE 1. Demographic characteristics of the patients with lung cancer

\begin{tabular}{|c|c|c|c|c|c|}
\hline \multirow[b]{2}{*}{ Characteristic } & \multirow[b]{2}{*}{ Cases } & & \multicolumn{3}{|c|}{ Recurrence } \\
\hline & & & No. of events* & HR $(95 \%$ CI $)$ & Log-rank test, $P$ value \\
\hline Total, no. & 388 & & 71 & & \\
\hline Age, y & & & & & .633 \\
\hline Mean \pm SD & $62.7 \pm 9.2$ & $<63.5 \ddagger$ & $36(19)$ & Reference & \\
\hline Median (range) & $63.5(34-85)$ & $\geq 63.5 \ddagger$ & $35(18)$ & $1.12(0.70-1.79)$ & \\
\hline Gender, no. & & & & & .017 \\
\hline Male, n (\%) & $259(67)$ & & $57(22)$ & Reference & \\
\hline Female, n $(\%)$ & $129(33)$ & & $14(11)$ & $0.49(0.27-0.88)$ & \\
\hline Smoking status, no. & & & & & .047 \\
\hline Never, n (\%) & $137(35)$ & & $17(12)$ & Reference & \\
\hline Ever, $\mathrm{n}(\%)$ & $251(65)$ & & $54(22)$ & $1.74(1.01-3.00)$ & \\
\hline Histology, no. & & & & & .004 \\
\hline Adenocarcinoma, n (\%) & $242(62)$ & & $32(13)$ & Reference & \\
\hline Squamous cell carcinoma, n (\%) & $146(38)$ & & $39(27)$ & $2.00(1.25-3.20)$ & \\
\hline Pathologic atage (AJCC 7th edition) & & & & & $<.001$ \\
\hline IA, n $(\%)$ & $135(35)$ & & $7(5)$ & Reference & \\
\hline $\mathrm{IB}, \mathrm{n}(\%)$ & $116(30)$ & & $21(18)$ & $4.31(1.83-10.16)$ & \\
\hline IIA, n (\%) & $43(11)$ & & $11(26)$ & $5.79(2.24-14.94)$ & \\
\hline IIB, n (\%) & $24(6)$ & & $6(25)$ & $6.24(2.09-18.59)$ & \\
\hline IIIA, n (\%) & $70(18)$ & & $26(37)$ & $11.60(5.02-26.80)$ & \\
\hline Postoperative complication & & & & & .133 \\
\hline No, n $(\%)$ & 297 (77) & & $52(18)$ & Reference & \\
\hline Yes, $\mathrm{n}(\%)$ & $91(23)$ & & $19(21)$ & $1.50(0.88-2.55)$ & \\
\hline Adjuvant chemotherapy & & & & & .495 \\
\hline No, n $(\%)$ & $303(78)$ & & $54(18)$ & Reference & \\
\hline Yes, n $(\%)$ & $85(22)$ & & $17(20)$ & $1.21(0.70-2.10)$ & \\
\hline \multicolumn{6}{|l|}{ Follow-up time, mo $\dagger$} \\
\hline Median $(95 \%$ CI $)$ & \multicolumn{5}{|c|}{$36.8(39.5-44.8)$} \\
\hline Range & \multicolumn{5}{|c|}{$(0.1-108.9)$} \\
\hline
\end{tabular}

variables. Age, gender, and smoking were not associated with any of the miRNA polymorphisms (Appendix Table 1). In 108 patients with nodal metastasis, there was no difference between micrometastasis and overt nodal metastasis and any of the miRNA polymorphisms. The CC genotype of the rs7372209 SNP was more evident in squamous cell carcinoma $(P=.014)$. The CC genotype of the rs2910164 SNP was associated with more advanced pathologic staging $(P=.036)$. In the multivariate analysis (Appendix Table 2), the CC genotype of the rs2910164 SNP was more frequently found in patients with stage II and IIIA disease than in those with stage I disease $(P<.01$; HR, 0.48; 95\% CI, 0.28-0.80).

\section{The Effects of miRNA Polymorphisms on RFS}

The rates for overall survival and RFS were $84.8 \%$ and $74.5 \%$ in all patients, respectively. The RFS was selected as the primary end point because additional treatment modalities could affect the survival of the patients after cancer recurrence. The association analysis between RFS and miRNA polymorphisms revealed that variants of the rs2910164 polymorphism in miR-146a were associated with an improved RFS in all of the patients (adjusted HR, $0.65 ; 95 \% \mathrm{CI}, 0.45-0.93 ; P=.019)$. Inasmuch as the pathologic stage of the cancer is an important factor that affects the clinical outcome, the effects of the polymorphisms on the RFS in stage I and higher-stage patients (stage II/III) were further evaluated with stratified analyses. As shown in Table 2, two polymorphisms were significantly associated with the survival of patients with stage II and III disease. Specifically, the rs2910164 allele was associated with an increased RFS in patients with a relatively advanced cancer stage (adjusted HR, 0.48; 95\% CI, 0.28$0.80 ; P=.005$ in an additive model). The Kaplan-Meier analysis revealed that the CC genotype of the rs2910164 SNP was associated with poor survival in patients with stage II and III disease $(\log -$ rank $P=.0047$; Figure 1$)$. Additionally, the rs11614913 allele in miR-196a 2 reduced the HR for the RFS in patients with advanced-stage cancer (adjusted HR, 0.60; 95\% CI, 0.38-0.94; $P=.026$ in an additive model). The cumulative effects of these 2 SNPs were evaluated in the patients, and the rs2910164 and rs11614913 variant alleles exhibited a trend toward associating with a prolonged RFS in patients with all stages of 
TABLE 2. The association between the 7 miRNA polymorphisms and the recurrence-free survival according to the pathologic stages of lung cancer

\begin{tabular}{|c|c|c|c|c|c|c|c|c|c|c|c|c|c|c|c|}
\hline \multirow[b]{2}{*}{ Genotypes } & \multicolumn{5}{|c|}{ Total $(\mathrm{n}=388)$} & \multicolumn{5}{|c|}{ Stage I (A/B) } & \multicolumn{5}{|c|}{ Stage II (A/B) and stage IIIA } \\
\hline & $\begin{array}{l}\text { No. of } \\
\text { pts. }\end{array}$ & $\begin{array}{c}\text { No. } \\
\text { relapsed }\end{array}$ & $\begin{array}{c}\text { Log-rank } \\
\text { trend test, } \\
P \text { value } \dagger\end{array}$ & $\begin{array}{l}\text { Adjusted } \\
\text { HR }\end{array}$ & $(95 \% \mathrm{CI}) *$ & $\begin{array}{c}\text { No. } \\
\text { of pts. }\end{array}$ & $\begin{array}{c}\text { No. } \\
\text { relapsed }\end{array}$ & $\begin{array}{c}\text { Log- rank } \\
\text { trend test, } \\
P \text { value } \dagger\end{array}$ & $\begin{array}{c}\text { Adjusted } \\
\text { HR }\end{array}$ & $(95 \% \text { CI })^{*}$ & $\begin{array}{l}\text { No. } \\
\text { of pts. }\end{array}$ & $\begin{array}{c}\text { No. } \\
\text { relapsed }\end{array}$ & $\begin{array}{c}\text { Log- rank } \\
\text { trend test, } \\
P \text { value } \dagger\end{array}$ & $\begin{array}{l}\text { Adjusted } \\
\text { HR }\end{array}$ & $(95 \% \mathbf{C I})^{*}$ \\
\hline \multicolumn{16}{|l|}{ mir219-1 rs213210 } \\
\hline AA & 105 & 17 & .56 & Ref. & & 75 & 7 & .515 & Ref. & & 30 & 10 & .91 & Ref. & \\
\hline $\mathrm{AG}$ & 182 & 35 & & 1.16 & $(0.65-2.08)$ & 113 & 12 & & 1.14 & $(0.44-2.95)$ & 69 & 23 & & 1.13 & $(0.53-2.41)$ \\
\hline GG & 100 & 19 & & 1.18 & $(0.60-2.31)$ & 62 & 9 & & 1.20 & $(0.43-3.38)$ & 38 & 10 & & 0.91 & $(0.37-2.24)$ \\
\hline $\mathrm{AG}+\mathrm{GG}$ & 282 & 54 & & 1.17 & $(0.67-2.03)$ & 175 & 21 & & 1.16 & $(0.48-2.81)$ & 107 & 33 & & 1.06 & $(0.51-2.18)$ \\
\hline \multicolumn{16}{|l|}{$\operatorname{mir} 27 a$ rs 895819} \\
\hline $\mathrm{TT}$ & 185 & 32 & .984 & Ref. & & 127 & 12 & .630 & Ref. & & 58 & 20 & .367 & Ref. & \\
\hline $\mathrm{CT}$ & 158 & 32 & & 1.03 & $(0.62-1.72)$ & 98 & 13 & & 1.46 & $(0.65-3.29)$ & 60 & 19 & & 0.93 & $(0.48-1.84)$ \\
\hline $\mathrm{CC}$ & 45 & 7 & & 0.81 & $(0.35-1.85)$ & 26 & 3 & & 1.20 & $(0.33-4.41)$ & 19 & 4 & & 0.64 & $(0.21-1.92)$ \\
\hline $\mathrm{CT}+\mathrm{CC}$ & 203 & 39 & & 0.98 & $(0.61-1.60)$ & 124 & 16 & & 1.4 & $(0.65-3.03)$ & 79 & 23 & & 0.86 & $(0.45-1.65)$ \\
\hline $\begin{array}{l}\text { Trend for } \mathrm{C} \text { allele } \\
\text { mir492 rs2289030 }\end{array}$ & & & & 0.94 & $(0.66-0.35)$ & & & & 1.20 & $(0.69-2.07)$ & & & & 0.84 & $(0.52-1.35)$ \\
\hline GG & 237 & 41 & .961 & Ref. & & 154 & 16 & .776 & Ref. & & 83 & 25 & .869 & Ref. & \\
\hline CG & 132 & 28 & & 1.12 & $(0.69-1.83)$ & 84 & 12 & & 1.37 & $(0.64-2.93)$ & 48 & 16 & & 1.08 & $(0.57-2.07)$ \\
\hline $\mathrm{CC}$ & 19 & 2 & & 0.56 & $(0.14-2.33)$ & 13 & 0 & & NA & & 6 & 2 & & 1.09 & $(0.25-4.69)$ \\
\hline $\mathrm{CG}+\mathrm{CC}$ & 151 & 30 & & 1.04 & $(0.65-1.69)$ & 97 & 12 & & 1.17 & $(0.55-2.48)$ & 54 & 18 & & 1.08 & $(0.58-2.02)$ \\
\hline $\begin{array}{l}\text { Trend for C allele } \\
\text { mir146a rs2910164 }\end{array}$ & & & & 0.96 & $(0.65-1.44)$ & & & & 0.95 & $(0.50-1.78)$ & & & & 1.07 & $(0.63-1.79)$ \\
\hline $\mathrm{CC}$ & 177 & 43 & .016 & Ref. & & 104 & 12 & .891 & Ref. & & 73 & 31 & .006 & Ref. & \\
\hline CG & 159 & 20 & & 0.52 & $(0.31-0.89)$ & 111 & 11 & & 0.75 & $(0.32-1.76)$ & 48 & 9 & & 0.39 & $(0.19-0.83)$ \\
\hline GG & 51 & 8 & & 0.53 & $(0.24-1.13)$ & 35 & 5 & & 1.11 & $(0.38-3.22)$ & 16 & 3 & & 0.30 & $(0.09-1.00)$ \\
\hline $\mathrm{CG}+\mathrm{GG}$ & 210 & 28 & & 0.52 & $(0.32-0.85)$ & 146 & 16 & & 0.84 & $(0.39-1.82)$ & 64 & 12 & & 0.37 & (0.19-0.71) \\
\hline $\begin{array}{l}\text { Trend for } \mathrm{G} \text { allele } \\
\text { mir423 rs6505162 }\end{array}$ & & & & 0.65 & $(0.45-0.93)$ & & & & 0.98 & $(0.57-1.7)$ & & & & 0.48 & $(0.28-0.80)$ \\
\hline $\mathrm{CC}$ & 244 & 44 & .887 & Ref. & & 157 & 16 & .691 & Ref. & & 87 & 28 & .866 & Ref. & \\
\hline $\mathrm{AC}$ & 120 & 24 & & 1.18 & $(0.71-1.95)$ & 78 & 11 & & 1.41 & $(0.65-3.08)$ & 42 & 13 & & 1.02 & $(0.52-2.00)$ \\
\hline $\mathrm{AA}$ & 21 & 3 & & 0.69 & $(0.21-2.24)$ & 14 & 1 & & 1.02 & $(0.13-7.97)$ & 7 & 2 & & 0.81 & $(0.19-3.41)$ \\
\hline $\mathrm{AC}+\mathrm{AA}$ & 141 & 27 & & 1.09 & $(0.67-1.77)$ & 92 & 12 & & 1.37 & $(0.64-2.94)$ & 49 & 15 & & 0.98 & $(0.51-1.87)$ \\
\hline Trend for A allele & & & & 1.00 & $(0.68-1.47)$ & & & & 1.24 & $(0.65-2.33)$ & & & & 0.96 & $(0.57-1.61)$ \\
\hline mir26a-1 rs7372209 & & & & & & & & & & & & & & & \\
\hline $\mathrm{CC}$ & 204 & 36 & .606 & Ref. & & 128 & 13 & .639 & Ref. & & 76 & 23 & .715 & Ref. & \\
\hline $\mathrm{CT}$ & 154 & 28 & & 1.16 & $(0.70-1.91)$ & 105 & 13 & & 1.29 & $(0.59-2.83)$ & 49 & 15 & & 1.03 & $(0.53-2.02)$ \\
\hline $\mathrm{TT}$ & 30 & 7 & & 1.14 & $(0.50-2.62)$ & 18 & 2 & & 1.64 & $(0.36-7.47)$ & 12 & 5 & & 1.34 & $(0.50-3.62)$ \\
\hline $\mathrm{CT}+\mathrm{TT}$ & 184 & 35 & & 1.16 & $(0.72-1.86)$ & 123 & 15 & & 1.33 & $(0.62-2.84)$ & 61 & 20 & & 1.10 & $(0.59-2.03)$ \\
\hline Trend for $\mathrm{T}$ allele & & & & 1.10 & $(0.77-1.57)$ & & & & 1.28 & $(0.70-2.36)$ & & & & 1.12 & $(0.71-1.76)$ \\
\hline
\end{tabular}


cancer (adjusted HR, 0.74; 95\% CI, 0.59-0.93; $P=.011$ ). However, the Kaplan-Meier analysis revealed that the effect of the 2 SNPs was only significant for patients with stage II and III cancer (Figure 2). The patients carrying a greater amount of variant alleles of these 2 SNPs had a significantly prolonged RFS (adjusted HR, 0.57; 95\% CI, 0.41-0.78; $P=.0005$; Table 3).

\section{Effect of Adjuvant Chemotherapy on Patient Outcome by miRNA SNPs}

Platinum-based adjuvant chemotherapy was prescribed in 85 patients at approximately 6 weeks after surgery. The most common treatment modality prescribed was gemcitabine (Gemzar; Eli Lilly, Indianapolis, Ind) plus cisplatin $(\mathrm{n}=32,38 \%)$. The rs2910164 allele was associated with a significantly altered risk of RFS in patients receiving chemotherapy (Appendix Table 3). In patients who received adjuvant chemotherapy, the recurrence of disease in patients who expressed the variant miRNA allele was $10.6 \%$, whereas the recurrence in the patients carrying the CC genotype was $31.6 \%(P=.003)$. Interestingly, a similar effect was shown by variant genotypes of rs11614913. In patients who received adjuvant chemotherapy, the recurrence rate in patients harboring the variant genotypes was $12.7 \%$, whereas the survival of the patients carrying the CC genotype was $42.9 \%(P=.037)$.

The patients who had lymph nodal metastasis $(\mathrm{n}=108)$ were dichotomized on the basis of whether micrometastases were discovered after the operation. The KaplanMeier analysis revealed that the CC genotype of the rs2910164 allele associates with poor survival in patients with micrometastasis (adjusted HR, 0.117; 95\% CI, $0.027-0.495 ; P=.004$ in an additive model). However, the sample number was too small to confidently draw conclusions (Appendix Table 4).

\section{DISCUSSION}

In this study, polymorphisms in certain miRNAs were significantly associated with lung cancer prognosis in patients who underwent complete resections. Genetic variants in miRNAs have been investigated as genetic markers to predict cancer susceptibility and prognosis. miRNA polymorphisms could have effects on cellular function through the regulation of the primary transcript levels, pre- miRNA and pri-miRNA processing, and the interaction between the miRNA and the target mRNA. ${ }^{12}$ Polymorphisms of the miRNA binding site have been suggested to be functional SNPs that affect the binding affinity of miRNAs to their targets. The functional significance of miRNA polymorphisms and the interaction between miRNA and mRNA make it feasible to evaluate the potential associations between miRNA polymorphisms and cancer prognosis. 

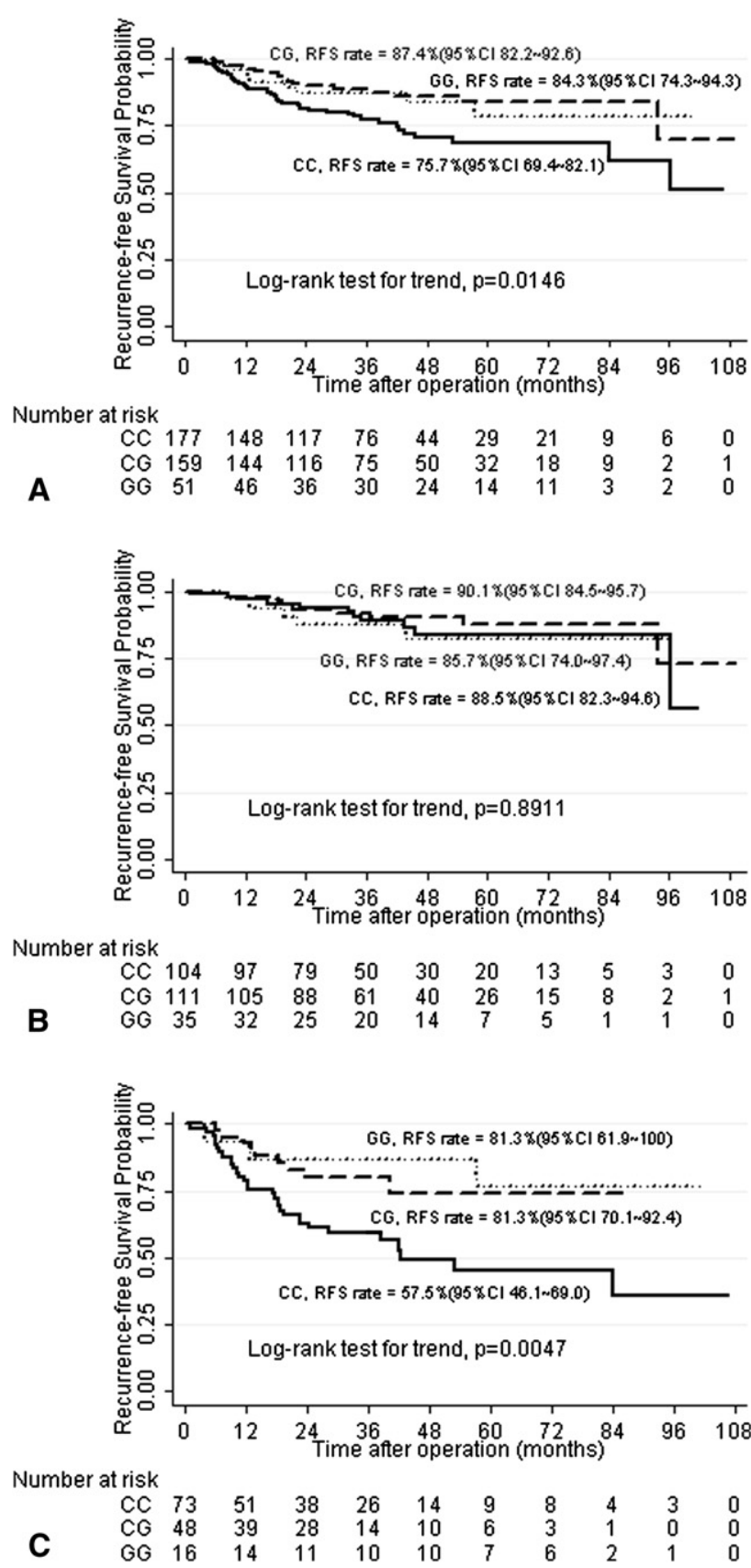

FIGURE 1. Recurrence-free survival $(R F S)$ of patients according to the rs2910164 genotypes by cancer stage. A, All. B, Stage I. C, Stages II and III. CI, Confidence interval.

In the current study, we analyzed the genotype frequencies and the clinical information from 388 patients to test the effects of 7 published miRNA polymorphisms on lung cancer recurrence. Among the miRNA SNPs analyzed, variants of the rs2910164 polymorphism in miR146a were strongly associated with RFS in patients with NSCLC. Patients with advanced-stage NSCLC who expressed the variant allele of the rs2910164 locus correlated with an increased RFS. Regarding survival, an association between the rs2910164 polymorphism and cancer has been reported in esophageal cancer, hepatocellular carcinoma, breast cancer, and thyroid cancer. ${ }^{20-23}$ The rs2910164 polymorphism represents a functional polymorphism in miR-146a that is located in the $3^{\prime}$ miRNA passenger strand and alters the expression of the mature sequence. The variant $\mathrm{G}$ allele of the rs 2910164 locus was associated with increased expression of mature miR-146a, and increased expression of miR-146a was found to suppress breast cancer metastasis. ${ }^{23}$ Recently, a potential therapeutic application of miR-146a was suggested for treating cancer. The inhibitory function of miR-146a on cancer invasion has also been reported in pancreatic cancer cells that overexpress epidermal growth factor receptor and its target, the nuclear factor- $\kappa \mathrm{B}$ regulatory kinase interleukin-1 receptor-associated kinase $1 .{ }^{24}$ Our results revealed a significant association between the rs 2910164 polymorphism and lung cancer prognosis in patients with advanced-stage disease, suggesting that the variant allele and the resultant increase in mature miR-146a levels might be involved in the inhibition of recurrence.

Variants of the rs 11614913 polymorphism found in miR$196 \mathrm{a} 2$ also exhibited a positive association with the RFS in patients with stage II/III disease. The association of rs11614913 with prognosis has been reported for various types of cancer. For example, patients who harbor the variant TT genotype have significantly reduced overall survival among patients with pharyngeal tumors. ${ }^{25}$ However, our data show that the TT genotype is associated with a poor RFS in early-stage patients only.

Given that the prognosis of cancer patients likely involves multistep, multigenic pathways, it is unlikely that any single miRNA polymorphism would have a dramatic effect on the survival outcome. Therefore, it is important to conduct pathway-based analyses that assess the combined effects of polymorphisms that might interact in the same pathway. To this end, we used a multigenic approach to evaluate the associations of miRNA SNPs with the survival and outcome of patients with surgically resected NSCLC. Our data reveal that 2 SNPs and their combined genotypes were associated with the survival outcome of patients with NSCLC. These findings suggest that SNPs in miRNAs, and particularly the combined genotypes of several SNPs, can be used as prognostic factors for patients with surgically resected NSCLC.

The most significant finding of this study was that the combined analysis of multiple SNPs in miRNAs that regulate the same or similar pathways had a much higher potential value in terms of revealing polymorphisms of prognostic importance. Although 2 SNPs were associated with the survival outcome in individual SNP analysis, considering the borderline $\mathrm{CI}$ and multiple comparisons, the impact of any individual miRNA SNP on survival outcomes is probably minimal. However, when these 2 SNPs were 

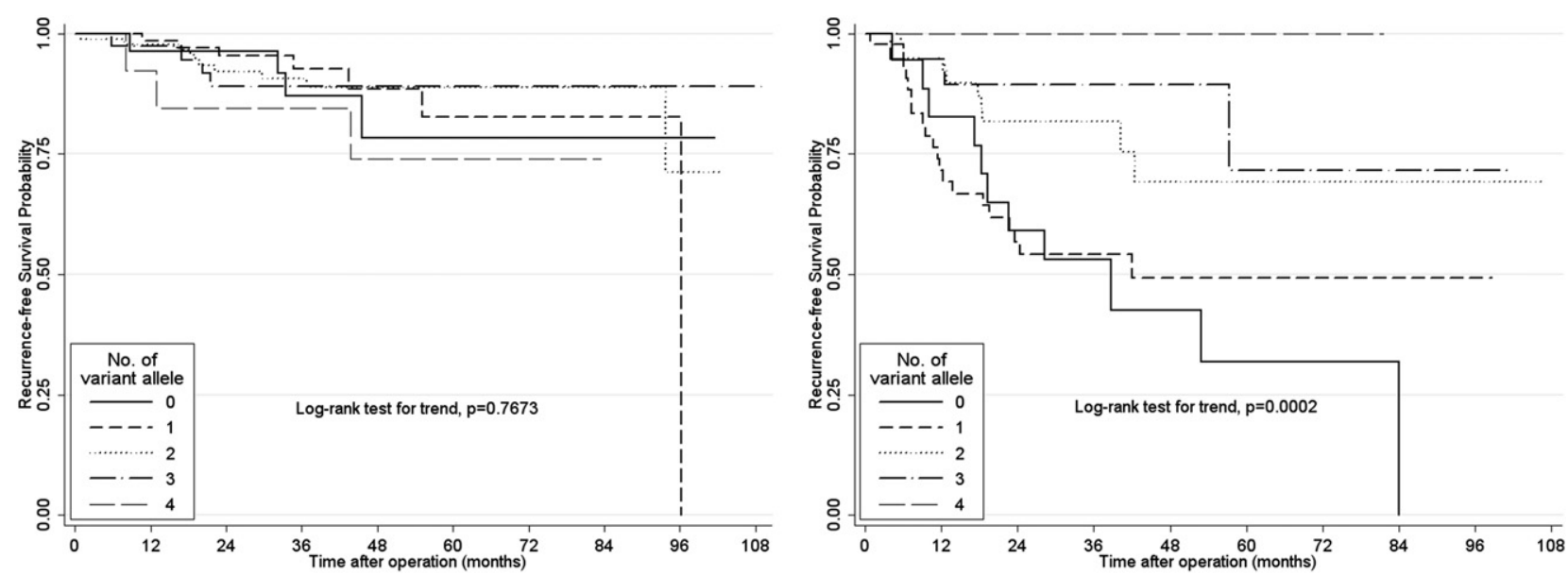

\begin{tabular}{|c|c|c|c|c|c|}
\hline & \multicolumn{5}{|c|}{ No. of variant allele } \\
\hline & 0 & 1 & 2 & 3 & 4 \\
\hline RFS rate, \% & 85.7 & 90.1 & 89.7 & 90.0 & 78.6 \\
$(95 \% \mathrm{CI})$ & $(72.7 \sim 98.8)$ & $(83.2 \sim 97.1)$ & $(83.6 \sim 95.8)$ & $(80.6 \sim 99.4)$ & $(56.9 \sim 100)$ \\
\hline
\end{tabular}

\begin{tabular}{|c|c|c|c|c|c|}
\hline & \multicolumn{5}{|c|}{ No. of variant allele } \\
\hline & 0 & 1 & 2 & 3 & 4 \\
\hline RFS rate, \% & 47.6 & 56.5 & 80.0 & 85.0 & 100 \\
$(95 \% \mathrm{CI})$ & $(26.0 \sim 69.3)$ & $(42.0 \sim 71.3)$ & $(68.2 \sim 91.8)$ & $(69.1 \sim 100)$ & $(100 \sim 100)$ \\
\hline
\end{tabular}

\begin{tabular}{|c|c|c|c|c|c|c|c|c|c|c|}
\hline \multirow{2}{*}{\begin{tabular}{|c|} 
Number at risk \\
No. of variant allele \\
\end{tabular}} & \multicolumn{10}{|c|}{ Time after operation(month) } \\
\hline & 0 & 12 & 24 & 36 & 48 & 60 & 72 & 84 & 96 & 108 \\
\hline 0 & 28 & 27 & 26 & 17 & 9 & 5 & 4 & 2 & 1 & 0 \\
\hline 1 & 71 & 67 & 53 & 32 & 18 & 12 & 5 & 2 & 1 & 0 \\
\hline 2 & 97 & 91 & 73 & 53 & 36 & 22 & 17 & 7 & 2 & 0 \\
\hline 3 & 40 & 37 & 29 & 20 & 15 & 11 & 5 & 3 & 2 & 1 \\
\hline 4 & 14 & 12 & 11 & 9 & 6 & 3 & 2 & 0 & 0 & 0 \\
\hline
\end{tabular}

\begin{tabular}{|c|c|c|c|c|c|c|c|c|c|c|}
\hline \multirow{2}{*}{$\begin{array}{c}\text { Number at risk } \\
\text { No. of variant allele }\end{array}$} & \multicolumn{10}{|c|}{ Time after operation(month) } \\
\hline & 0 & 12 & 24 & 36 & 48 & 60 & 72 & 84 & 96 & 108 \\
\hline 0 & 21 & 14 & 10 & 7 & 4 & 3 & 3 & 0 & 0 & 0 \\
\hline 1 & 46 & 30 & 22 & 15 & 10 & 5 & 4 & 3 & 2 & 0 \\
\hline 2 & 45 & 37 & 26 & 15 & 11 & 8 & 5 & 2 & 1 & 0 \\
\hline 3 & 20 & 18 & 14 & 9 & 6 & 4 & 3 & 2 & 1 & 0 \\
\hline 4 & 3 & 3 & 3 & 3 & 3 & 2 & 2 & 0 & 0 & 0 \\
\hline
\end{tabular}

FIGURE 2. Kaplan-Meier curves showing the recurrence-free survival (RFS) probability according to the number of variant alleles from the combination of the rs2910164 (G allele) and rs11614913 (C allele) polymorphisms by cancer stage. A, Stage I. B, Stages II and III. CI, Confidence interval.

TABLE 3. The additive effects of the combination of rs2910164 ( $\mathrm{G}$ allele) and rs11614913 ( $\mathrm{C}$ allele) on the recurrence-free survival according to the clinical stages of lung cancer patients

\begin{tabular}{|c|c|c|c|c|c|c|c|c|}
\hline \multirow[b]{2}{*}{ Pathologic stage } & \multirow{2}{*}{$\begin{array}{c}\text { rs2910164 (G allele }) \\
\text { \& rs11614913 }(\mathrm{C} \text { allele }) \\
\text { combined } \\
\end{array}$} & \multirow[b]{2}{*}{ No. of patients } & \multirow[b]{2}{*}{ No. relapsed } & \multirow{2}{*}{$\begin{array}{l}\text { Recurrence } \\
\text { rate, } \%\end{array}$} & \multirow{2}{*}{$\begin{array}{c}\text { Log-rank trend } \\
\text { test, } P \text { value* }\end{array}$} & \multicolumn{2}{|c|}{ Adjusted } & \multirow{2}{*}{$\begin{array}{c}P \\
\text { value }\end{array}$} \\
\hline & & & & & & HR & $(95 \% \mathrm{CI}) \dagger$ & \\
\hline \multirow[t]{6}{*}{ All } & 0 variant alleles & 49 & 15 & 31 & .0039 & Ref. & & \\
\hline & 1 variant allele & 117 & 27 & 23 & & 0.82 & $(0.43-1.55)$ & .5368 \\
\hline & 2 variant alleles & 142 & 19 & 13 & & 0.48 & $(0.24-0.95)$ & .0351 \\
\hline & 3 variant alleles & 60 & 7 & 12 & & 0.36 & $(0.15-0.88)$ & .0258 \\
\hline & 4 variant alleles & 17 & 3 & 18 & & 0.63 & $(0.18-2.22)$ & .4755 \\
\hline & Trend & & & & & 0.74 & $(0.59-0.93)$ & .0113 \\
\hline \multirow[t]{6}{*}{ Stage I } & 0 variant alleles & 28 & 4 & 14 & .7667 & Ref. & & \\
\hline & 1 variant allele & 71 & 7 & 10 & & 0.95 & $(0.27-3.31)$ & .9324 \\
\hline & 2 variant alleles & 97 & 10 & 10 & & 0.79 & $(0.24-2.60)$ & .6976 \\
\hline & 3 variant alleles & 40 & 4 & 10 & & 0.68 & $(0.17-2.79)$ & .5959 \\
\hline & 4 variant alleles & 14 & 3 & 21 & & 1.56 & $(0.34-7.13)$ & .5688 \\
\hline & Trend & & & & & 1.00 & $(0.70-1.43)$ & .9922 \\
\hline \multirow[t]{6}{*}{ Stages II and IIIA } & 0 variant alleles & 21 & 11 & 52 & .0003 & Ref. & & \\
\hline & 1 variant allele & 46 & 20 & 43 & & 0.82 & $(0.39-1.75)$ & .6126 \\
\hline & 2 variant alleles & 45 & 9 & 20 & & 0.35 & $(0.14-0.85)$ & .0208 \\
\hline & 3 variant alleles & 20 & 3 & 15 & & 0.22 & $(0.06-0.79)$ & .0207 \\
\hline & 4 variant alleles & 3 & 0 & 0 & & & NA & .9875 \\
\hline & Trend & & & & & 0.57 & $(0.41-0.78)$ & .0005 \\
\hline
\end{tabular}

$H R$, Hazard ratio; CI, confidence interval; Ref., reference. $*$ Trend for an increasing number of variant alleles. †The HRs and $95 \%$ CIs were derived from a Cox proportionalhazard regression model controlling for age, gender, smoking status, histologic tumor type, stage, and postoperative complications as covariates. 
combined, the RFS correlated significantly with a higher number of polymorphisms that confer an increased RFS when analyzed individually.

Our study was limited to patients who underwent complete resection without prior treatment and focused on the patient RFS to avoid heterogeneity in the interpretation of the results. However, further biological and/or functional evidence is needed to confirm the genetic effects of these polymorphisms on lung cancer prognosis in these patients. Despite the importance of the protective effect of these miRNA polymorphisms on the RFS of NSCLC patients who underwent complete resections, this study only considered the Korean population, which may limit the application of these findings to other ethnicities. Furthermore, the subset analysis with respect to cancer stage was limited by the sample size, particularly for patients with stages II and III NSCLC.

In conclusion, the results indicated that there is a significant association between miRNA polymorphisms and NSCLC prognosis. These results suggest that the presence of variant alleles in miR-146a and miR-196a2 may serve as prognostic markers for the recurrence of completely resected lung cancer.

We are indebted to Geon Kook Lee, MD, $\mathrm{PhD}$, who provided the samples from the tumor bank of National Cancer Center in Korea. We also thank Jihye Han and Mee Kyung Jung at the National Cancer Center in Korea for data collection and statistical review.

\section{References}

1. Lee Y, Jeon K, Lee JT, Kim S, Kim VN. MicroRNA maturation: stepwise processing and subcellular localization. EMBO J. 2002;21:4663-70.

2. Bartel DP. MicroRNAs: genomics, biogenesis, mechanism, and function. Cell. 2004;116:281-97.

3. Murchison EP, Hannon GJ. miRNAs on the move: miRNA biogenesis and the RNAi machinery. Curr Opin Cell Biol. 2004;16:223-9.

4. Zeng Y, Yi R, Cullen BR. Recognition and cleavage of primary microRNA precursors by the nuclear processing enzyme Drosha. EMBO J. 2005;24:138-48.

5. Kwak PB, Iwasaki S, Tomari Y. The microRNA pathway and cancer. Cancer Sci. 2010;101:2309-15.

6. Gregory RI, Shiekhattar R. MicroRNA biogenesis and cancer. Cancer Res. 2005; 65:3509-12.
7. Sassen S, Miska EA, Caldas C. MicroRNA: implications for cancer. Virchows Arch. 2008;452:1-10.

8. Takamizawa J, Konishi H, Yanagisawa K, Tomida S, Osada H, Endoh H, et al. Reduced expression of the let-7 microRNAs in human lung cancers in association with shortened postoperative survival. Cancer Res. 2004;64:3753-6.

9. Johnson SM, Grosshans H, Shingara J, Byrom M, Jarvis R, Cheng A, et al. RAS is regulated by the let-7 microRNA family. Cell. 2005;120:635-47.

10. Blitzblau RC, Weidhaas JB. MicroRNA binding-site polymorphisms as potential biomarkers of cancer risk. Mol Diagn Ther. 2010;14:355-2.

11. Ryan BM, Robles AI, Harris CC. Genetic variation in microRNA networks: the implications for cancer research. Nat Rev Cancer. 2010;10:389-402.

12. Ye Y, Wang KK, Gu J, Yang H, Lin J, Ajani JA, et al. Genetic variations in microRNA-related genes are novel susceptibility loci for esophageal cancer risk. Cancer Prev Res (Phila). 2008;1:460-9

13. Boni V, Zarate R, Villa JC, Bandrés E, Gomez MA, Maiello E, et al. Role of primary miRNA polymorphic variants in metastatic colon cancer patients treated with 5-fluorouracil and irinotecan. Pharmacogenomics J. 2011;11:429-36.

14. Yang H, Dinney CP, Ye Y, Zhu Y, Grossman HB, Wu X. Evaluation of genetic variants in microRNA-related genes and risk of bladder cancer. Cancer Res. 2008;68:2530-7.

15. Sun Q, Gu H, Zeng Y, Xia Y, Wang Y, Jing Y, et al. Hsa-mir-27a genetic variant contributes to gastric cancer susceptibility through affecting miR-27a and target gene expression. Cancer Sci. 2010;101:2241-7.

16. Yang R, Schlehe B, Hemminki K, Sutter C, Bugert P, Wappenschmidt B, et al. A genetic variant in the pre-miR-27a oncogene is associated with a reduced familia breast cancer risk. Breast Cancer Res Treat. 2010;121:693-702.

17. Hu Z, Chen J, Tian T, Zhou X, Gu H, Xu L, et al. Genetic variants of miRNA sequences and non-small cell lung cancer survival. J Clin Invest. 2008;118:2600-8.

18. Permuth-Wey J, Thompson RC, Burton Nabors L, Olson JJ, Browning JE, Madden $\mathrm{MH}$, et al. A functional polymorphism in the pre-miR-146a gene is associated with risk and prognosis in adult glioma. J Neurooncol. 2011;105:639-46.

19. Guo $\mathrm{H}$, Wang $\mathrm{K}$, Xiong $\mathrm{G}, \mathrm{Hu} \mathrm{H}$, Wang $\mathrm{D}$, Xu X, et al. A functional varient in microRNA-146a is associated with risk of esophageal squamous cell carcinoma in Chinese Han. Fam Cancer. 2010;9:599-603.

20. Jazdzewski K, Liyanarachchi S, Swierniak M, Pachucki J, Ringel MD, Jarzab B et al. Polymorphic mature microRNAs from passenger strand of pre-miR-146a contribute to thyroid cancer. Proc Natl Acad Sci U S A. 2009;106:1502-5.

21. Xu T, Zhu Y, Wei QK, Yuan Y, Zhou F, Ge YY, et al. A functional polymorphism in the miR-146a gene is associated with the risk for hepatocellular carcinoma. Carcinogenesis. 2008;29:2126-31.

22. Jazdzewski K, Murray EL, Franssila K, Jarzab B, Schoenberg DR, de la Chapelle A. Common SNP in pre-miR-146a decreases mature miR expression and predisposes to papillary thyroid carcinoma. Proc Natl Acad Sci U S A. 2008;105:7269-74

23. Hurst DR, Edmonds MD, Scott GK, Benz CC, Vaidya KS, Welch DR. Breast cancer metastasis suppressor 1 up-regulates miR-146, which suppresses breast cancer metastasis. Cancer Res. 2009;69:1279-83.

24. Li Y, Vandenboom TG 2nd, Wang Z, Kong D, Ali S, Philip PA, et al. miR-146a suppresses invasion of pancreatic cancer cells. Cancer Res. 2010;70:1486-95.

25. Christensen BC, Avissar-Whiting M, Ouellet LG, Butler RA, Nelson HH, McClean MD, et al. Mature microRNA sequence polymorphism in MIR196A2 is associated with risk and prognosis of head and neck cancer. Clin Cancer Res. 2010;16:3713-20. 


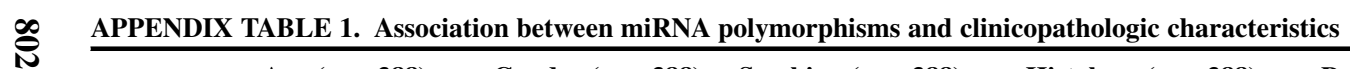

\begin{tabular}{|c|c|c|c|c|c|c|c|c|c|c|c|c|c|c|c|c|c|c|c|c|c|}
\hline & \multicolumn{3}{|c|}{ Age $(n=388)$} & \multicolumn{3}{|c|}{ Gender $(\mathbf{n}=\mathbf{3 8 8})$} & \multicolumn{3}{|c|}{ Smoking $(\mathrm{n}=388)$} & \multicolumn{3}{|c|}{ Histology $(n=388)$} & \multicolumn{3}{|c|}{ P staging $(n=388)$} & \multicolumn{3}{|c|}{ Postop. complication $(n=388)$} & \multicolumn{3}{|c|}{ Nodal metastasis $(\mathrm{n}=108)$} \\
\hline & $<63.5$ & $\geq 63.5$ & $\begin{array}{c}\chi^{2} \\
P \text { value }\end{array}$ & $\mathbf{M}$ & $\mathbf{F}$ & $\begin{array}{c}\chi^{2} \\
P \text { value } \\
\end{array}$ & Never & Ever & $\begin{array}{c}\chi^{2} \\
P \text { value } \\
\end{array}$ & Adeno & Squamous & $\begin{array}{c}\chi^{2} \\
P \text { value }\end{array}$ & I & II/IIIA & $\begin{array}{c}\chi^{2} \\
P \text { value } \\
\end{array}$ & No & Yes & $\begin{array}{c}\chi^{2} \\
P \text { value }\end{array}$ & Micrometa & $\begin{array}{c}\text { Overt } \\
\text { meta }\end{array}$ & $\begin{array}{c}\chi^{2} \\
P \text { value } \\
\end{array}$ \\
\hline \multicolumn{22}{|l|}{ rs213210 } \\
\hline AA & 46 & 59 & & 64 & 41 & & 45 & 60 & & 72 & 33 & & 75 & 30 & & 85 & 20 & & 8 & 15 & \\
\hline AG & 93 & 89 & & 121 & 61 & & 63 & 119 & & 113 & 69 & & 113 & 69 & & 139 & 43 & & 20 & 34 & \\
\hline GG & 54 & 46 & .311 & 74 & 26 & .137 & 28 & 72 & .082 & 56 & 44 & .178 & 62 & 38 & .230 & 72 & 28 & .319 & 12 & 19 & .957 \\
\hline $\mathrm{AG}+\mathrm{GG}$ & 147 & 135 & .180 & 195 & 87 & .161 & 91 & 191 & .069 & 169 & 113 & .149 & 175 & 107 & .111 & 211 & 71 & .259 & 32 & 53 & .993 \\
\hline \multicolumn{22}{|c|}{ rs 895819} \\
\hline TT & 98 & 87 & & 129 & 56 & & 62 & 123 & & 118 & 67 & & 127 & 58 & & 135 & 50 & & 15 & 31 & \\
\hline $\mathrm{CT}$ & 77 & 81 & & 97 & 61 & & 59 & 99 & & 101 & 57 & & 98 & 60 & & 125 & 33 & & 17 & 28 & \\
\hline $\mathrm{CC}$ & 19 & 26 & .398 & 33 & 12 & .160 & 16 & 29 & .760 & 23 & 22 & .253 & 26 & 19 & .259 & 37 & 8 & .259 & 8 & 9 & .568 \\
\hline $\mathrm{CT}+\mathrm{CC}$ & 96 & 107 & .309 & 130 & 73 & .280 & 75 & 128 & .548 & 124 & 79 & .657 & 124 & 79 & .147 & 162 & 41 & .143 & 25 & 37 & .536 \\
\hline \multicolumn{22}{|l|}{ rs2289030 } \\
\hline GG & 118 & 119 & & 156 & 81 & & 81 & 156 & & 146 & 91 & & 154 & 83 & & 178 & 59 & & 23 & 39 & \\
\hline CG & 68 & 64 & & 88 & 44 & & 52 & 80 & & 86 & 46 & & 84 & 48 & & 106 & 26 & & 15 & 26 & \\
\hline $\mathrm{CC}$ & 8 & 11 & .741 & 15 & 4 & .505 & 4 & 15 & .248 & 10 & 9 & .532 & 13 & 6 & .910 & 13 & 6 & .366 & 2 & 3 & .989 \\
\hline $\mathrm{CG}+\mathrm{CC}$ & 76 & 75 & 1.00 & 103 & 48 & .707 & 56 & 95 & .634 & 96 & 55 & .777 & 97 & 54 & .968 & 119 & 32 & .474 & 17 & 29 & 1.000 \\
\hline \multicolumn{22}{|l|}{ rs2910164 } \\
\hline $\mathrm{CC}$ & 91 & 86 & & 116 & 61 & & 65 & 112 & & 107 & 70 & & 104 & 73 & & 139 & 38 & & 23 & 35 & \\
\hline CG & 77 & 82 & & 104 & 55 & & 59 & 100 & & 106 & 53 & & 111 & 48 & & 121 & 38 & & 14 & 23 & \\
\hline GG & 25 & 26 & .854 & 39 & 12 & .298 & 12 & 39 & .175 & 28 & 23 & .255 & 35 & 16 & .087 & 36 & 15 & .494 & 3 & 10 & .531 \\
\hline $\mathrm{CG}+\mathrm{GG}$ & 102 & 108 & .649 & 143 & 67 & .671 & 71 & 139 & .623 & 134 & 76 & .566 & 146 & 64 & .036 & 157 & 53 & .453 & 17 & 33 & .684 \\
\hline \multicolumn{22}{|l|}{ rs6505162 } \\
\hline $\mathrm{CC}$ & 117 & 127 & & 170 & 74 & & 80 & 164 & & 151 & 93 & & 157 & 87 & & 183 & 61 & & 28 & 37 & \\
\hline $\mathrm{AC}$ & 61 & 59 & & 75 & 45 & & 47 & 73 & & 75 & 45 & & 78 & 42 & & 92 & 28 & & 9 & 26 & \\
\hline AA & 14 & 7 & .250 & 13 & 8 & .344 & 8 & 13 & .466 & 14 & 7 & .909 & 14 & 7 & .974 & 19 & 2 & .276 & 2 & 5 & .206 \\
\hline $\mathrm{AC}+\mathrm{AA}$ & 75 & 66 & .376 & 88 & 53 & .178 & 55 & 86 & .262 & 89 & 52 & .895 & 92 & 49 & .946 & 111 & 30 & .481 & 11 & 31 & .117 \\
\hline \multicolumn{22}{|l|}{ rs7372209 } \\
\hline $\mathrm{CC}$ & 103 & 101 & & 144 & 60 & & 66 & 138 & & 115 & 89 & & 128 & 76 & & 153 & 51 & & 24 & 38 & \\
\hline $\mathrm{CT}$ & 73 & 81 & & 96 & 58 & & 57 & 97 & & 106 & 48 & & 105 & 49 & & 120 & 34 & & 13 & 26 & \\
\hline $\mathrm{TT}$ & 18 & 12 & .441 & 19 & 11 & .239 & 14 & 16 & .263 & 21 & 9 & .037 & 18 & 12 & .485 & 24 & 6 & .729 & 3 & 4 & .816 \\
\hline $\mathrm{CT}+\mathrm{TT}$ & 91 & 93 & .919 & 115 & 69 & .114 & 71 & 113 & .239 & 127 & 57 & .014 & 123 & 61 & .461 & 144 & 40 & .524 & 16 & 30 & .829 \\
\hline \multicolumn{22}{|c|}{ rs11614913 } \\
\hline $\mathrm{TT}$ & 57 & 42 & & 64 & 35 & & 35 & 64 & & 66 & 33 & & 63 & 36 & & 80 & 19 & & 11 & 17 & \\
\hline $\mathrm{CT}$ & 94 & 92 & & 127 & 59 & & 66 & 120 & & 112 & 74 & & 116 & 70 & & 129 & 57 & & 15 & 37 & \\
\hline $\mathrm{CC}$ & 42 & 59 & .076 & 66 & 35 & .788 & 36 & 65 & .999 & 64 & 37 & .555 & 72 & 29 & .301 & 86 & 15 & .005 & 14 & 12 & .098 \\
\hline $\mathrm{CT}+\mathrm{CC}$ & 136 & 151 & .103 & 193 & 94 & .727 & 102 & 185 & 1.000 & 176 & 111 & .408 & 188 & 99 & .831 & 215 & 72 & .292 & 29 & 49 & 1.000 \\
\hline
\end{tabular}


APPENDIX TABLE 2. Multivariate analysis of clinicopathologic characteristics with the miRNA polymorphisms

\begin{tabular}{|c|c|c|c|c|c|c|c|}
\hline \multicolumn{4}{|c|}{ P staging $(\mathrm{n}=388)$} & \multicolumn{2}{|c|}{ Stage I } & \multicolumn{2}{|c|}{ Stage II/IIIA } \\
\hline rs2910164 & $\mathbf{I}$ & II/IIIA & $\chi^{2} P$ value & HR $(95 \%$ CI $)$ & $\chi^{2} P$ value & HR $(95 \%$ CI $)$ & $\chi^{2} P$ value \\
\hline$\overline{\mathrm{CC}}$ & 104 & 73 & & 1 & & 1 & \\
\hline $\mathrm{CG}$ & 111 & 48 & & $0.75(0.32-1.76)$ & .5141 & $0.39(0.19-0.83)$ & .0143 \\
\hline GG & 35 & 16 & .087 & $1.11(0.38-3.22)$ & .8512 & $0.30(0.09-1.00)$ & .0494 \\
\hline $\mathrm{CG}+\mathrm{GG}$ & 146 & 64 & .036 & $0.84(0.39-1.82)$ & .6649 & $0.37(0.19-0.72)$ & .0033 \\
\hline Trend & & & & $0.98(0.57-1.70)$ & .9504 & $0.48(0.28-0.80)$ & .0054 \\
\hline
\end{tabular}

\begin{tabular}{|c|c|c|c|c|c|c|c|}
\hline \multicolumn{4}{|c|}{ Histology $(n=388)$} & \multicolumn{2}{|c|}{ Adeno } & \multicolumn{2}{|c|}{ Squamous } \\
\hline rs7372209 & Adeno & Squamous & $\chi^{2} P$ value & HR $(95 \%$ CI $)$ & $\chi^{2} P$ value & HR $(95 \%$ CI $)$ & $\chi^{2} P$ value \\
\hline $\mathrm{CC}$ & 115 & 89 & & 1 & & 1 & \\
\hline $\mathrm{CT}$ & 106 & 48 & & $0.83(0.39-1.77)$ & .6238 & $1.55(0.79-3.02)$ & .1993 \\
\hline $\mathrm{TT}$ & 21 & 9 & .037 & $1.82(0.59-5.57)$ & .2970 & $0.93(0.27-3.25)$ & .9101 \\
\hline $\mathrm{CT}+\mathrm{TT}$ & 127 & 57 & .014 & $0.95(0.47-1.93)$ & .8960 & $1.41(0.74-2.67)$ & .2940 \\
\hline Trend & & & & $1.13(0.64-1.98)$ & .6728 & $1.59(0.73-1.85)$ & .5395 \\
\hline
\end{tabular}

\begin{tabular}{|c|c|c|c|c|c|c|c|}
\hline \multicolumn{4}{|c|}{ Postop. complication $(\mathrm{n}=388)$} & \multicolumn{2}{|c|}{ No } & \multicolumn{2}{|c|}{ Yes } \\
\hline rs11614913 & No & Yes & $\chi^{2} P$ value & HR $(95 \%$ CI $)$ & $\chi^{2} P$ value & HR $(95 \%$ CI $)$ & $\chi^{2} P$ value \\
\hline TT & 80 & 19 & & 1 & & 1 & \\
\hline $\mathrm{CT}$ & 129 & 57 & & $0.57(0.30-1.08)$ & .0819 & $0.62(0.20-1.93)$ & .4065 \\
\hline $\mathrm{CC}$ & 86 & 15 & .005 & $0.61(0.29-1.27)$ & .1841 & $0.77(0.17-3.45)$ & .7325 \\
\hline $\mathrm{CT}+\mathrm{CC}$ & 215 & 72 & .292 & $0.58(0.33-1.04)$ & .0664 & $0.65(0.22-1.94)$ & .4372 \\
\hline Trend & & & & $0.76(0.51-1.11)$ & .1559 & $0.84(0.37-1.88)$ & .6638 \\
\hline
\end{tabular}

HR, Hazard ratio; $C I$, confidence interval. 
$\stackrel{0}{\circ}$ APPENDIX TABLE 3. The association between the 7 miRNA SNPs and RFS according to adjuvant chemotherapy

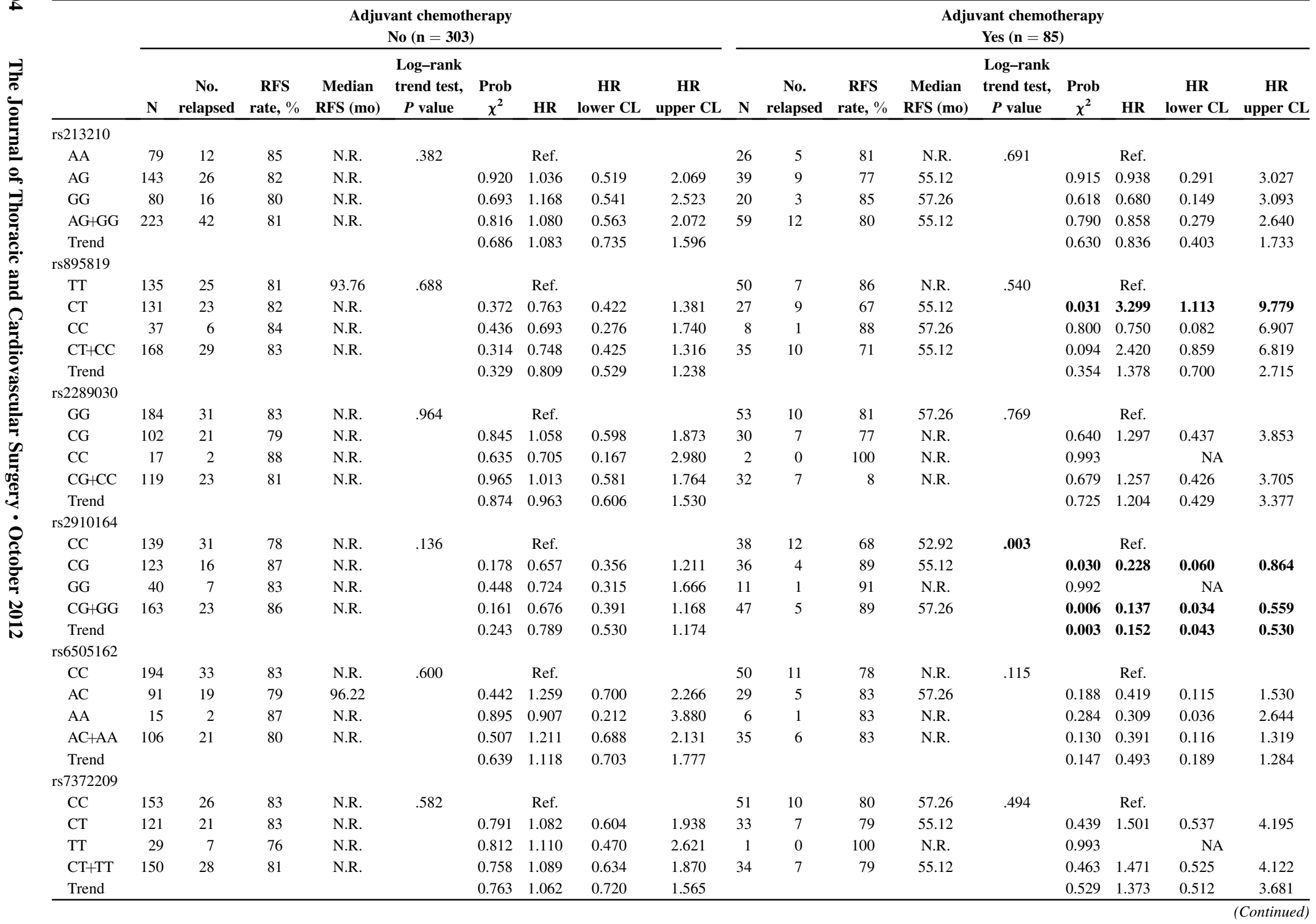


APPENDIX TABLE 3. Continued

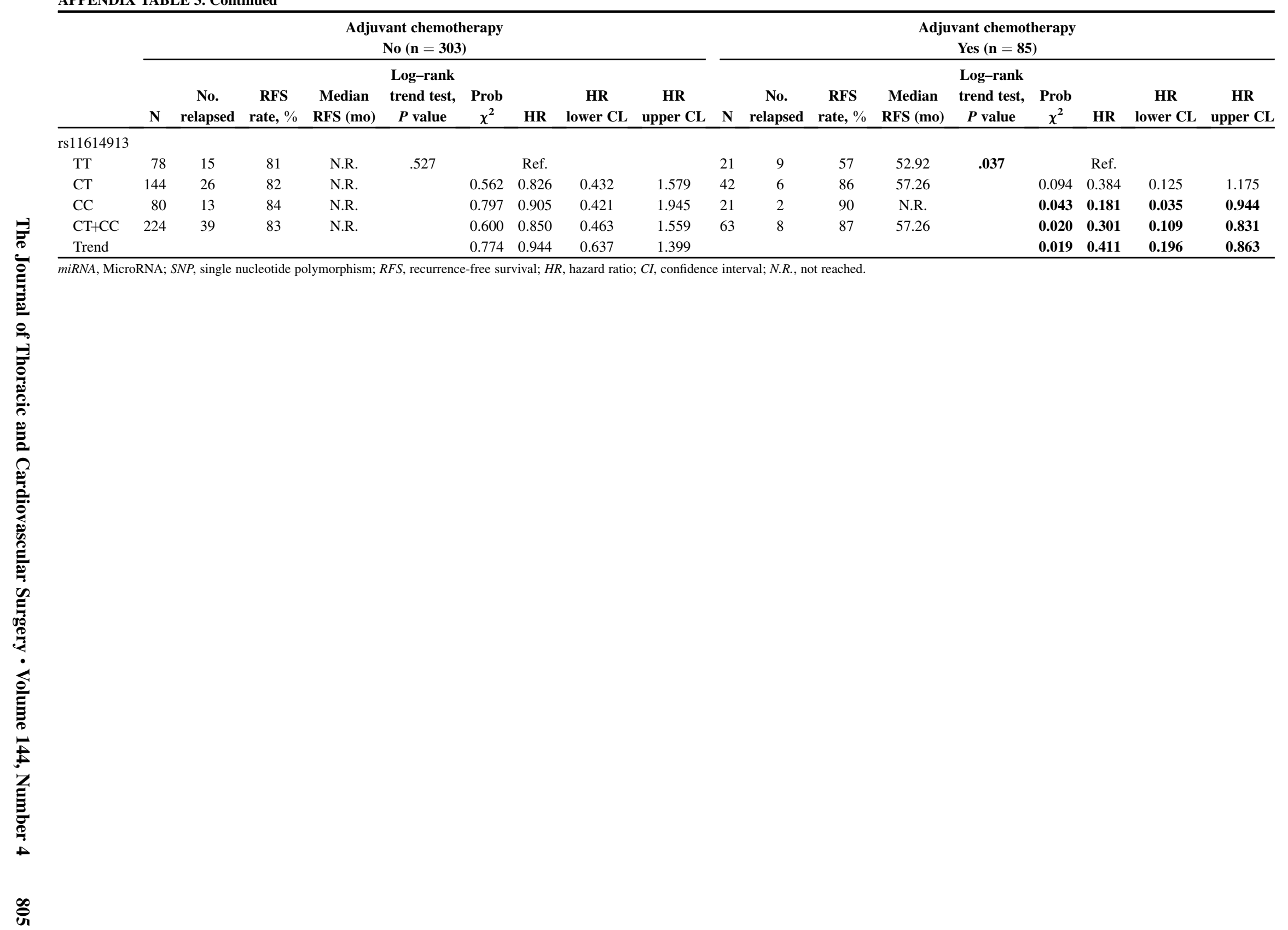


$\stackrel{\circ}{\mathscr{\rho}}$ APPENDIX TABLE 4. The association between the 7 miRNA SNPs and RFS according to the pattern of nodal metastasis

\begin{tabular}{|c|c|c|c|c|c|c|c|c|c|c|c|c|c|c|c|c|c|c|}
\hline & \multicolumn{9}{|c|}{ Micrometastasis $(n=40)$} & \multicolumn{9}{|c|}{ Overt nodal metatstasis $(n=68)$} \\
\hline & $\mathbf{N}$ & $\begin{array}{c}\text { No. } \\
\text { relapsed }\end{array}$ & $\begin{array}{c}\text { RFS } \\
\text { rate, \% }\end{array}$ & $\begin{array}{c}\text { Median } \\
\text { RFS (mo) }\end{array}$ & $\begin{array}{c}\text { Log-rank } \\
\text { trend test, } \\
P \text { value }\end{array}$ & $\begin{array}{c}\text { Prob } \\
\chi^{2}\end{array}$ & HR & $\begin{array}{c}\text { HR } \\
\text { lower } \mathrm{CL}\end{array}$ & $\begin{array}{c}\text { HR } \\
\text { upper CL }\end{array}$ & $\mathbf{N}$ & $\begin{array}{c}\text { No. } \\
\text { relapsed }\end{array}$ & $\begin{array}{c}\text { RFS } \\
\text { rate, \% }\end{array}$ & $\begin{array}{c}\text { Median } \\
\text { RFS (mo) }\end{array}$ & $\begin{array}{c}\text { Log-rank } \\
\text { trend test, } \\
P \text { value }\end{array}$ & $\begin{array}{c}\text { Prob } \\
\chi^{2}\end{array}$ & HR & $\begin{array}{c}\text { HR } \\
\text { lower CL }\end{array}$ & $\begin{array}{c}\text { HR } \\
\text { upper CL }\end{array}$ \\
\hline \multicolumn{19}{|l|}{ rs 213210} \\
\hline AA & 8 & 4 & 50 & 52.92 & .774 & & Ref. & & & 15 & 5 & 67 & N.R. & .784 & & Ref. & & \\
\hline AG & 20 & 7 & 65 & N.R. & & 0.778 & 0.803 & 0.174 & 3.699 & 34 & 12 & 65 & 41.98 & & 0.988 & 0.991 & 0.336 & 2.930 \\
\hline GG & 12 & 4 & 67 & 42.38 & & 0.551 & 1.768 & 0.272 & 11.494 & 19 & 5 & 74 & N.R. & & 0.687 & 0.765 & 0.207 & 2.823 \\
\hline $\mathrm{AG}+\mathrm{GG}$ & 32 & 11 & 66 & N.R. & & 0.963 & 0.966 & 0.230 & 4.067 & 53 & 17 & 68 & N.R. & & 0.872 & 0.918 & 0.323 & 2.608 \\
\hline Trend & & & & & & 0.595 & 1.301 & 0.492 & 3.439 & & & & & & 0.677 & 0.874 & 0.463 & 1.648 \\
\hline \multicolumn{19}{|l|}{ rs895819 } \\
\hline TT & 15 & 5 & 67 & N.R. & .710 & & Ref. & & & 31 & 13 & 58 & 40.24 & .083 & & Ref. & & \\
\hline $\mathrm{CT}$ & 17 & 8 & 53 & 42.38 & & 0.247 & 2.355 & 0.552 & 10.040 & 28 & 7 & 75 & N.R. & & 0.024 & 0.310 & 0.113 & 0.855 \\
\hline $\mathrm{CC}$ & 8 & 2 & 75 & N.R. & & 0.837 & 1.204 & 0.206 & 7.056 & 9 & 2 & 78 & N.R. & & 0.108 & 0.280 & 0.059 & 1.320 \\
\hline $\mathrm{CT}+\mathrm{CC}$ & 25 & 10 & 60 & 42.38 & & 0.343 & 1.829 & 0.525 & 6.369 & 37 & 9 & 76 & N.R. & & 0.014 & 0.303 & 0.117 & 0.782 \\
\hline Trend & & & & & & 0.577 & 1.246 & 0.576 & 2.694 & & & & & & 0.030 & 0.426 & 0.198 & 0.919 \\
\hline rs 2289030 & & & & & & & & & & & & & & & & & & \\
\hline GG & 23 & 8 & 65 & 52.92 & .669 & & Ref. & & & 39 & 13 & 67 & 57.26 & .711 & & Ref. & & \\
\hline $\mathrm{CG}$ & 15 & 6 & 60 & N.R. & & 0.431 & 0.592 & 0.161 & 2.180 & 26 & 8 & 69 & N.R. & & 0.519 & 0.731 & 0.281 & 1.897 \\
\hline $\mathrm{CC}$ & 2 & 1 & 50 & N.R. & & 0.267 & 4.212 & 0.332 & 53.428 & 3 & 1 & 67 & N.R. & & 0.885 & 0.856 & 0.104 & 7.046 \\
\hline $\mathrm{CG}+\mathrm{CC}$ & 17 & 7 & 59 & N.R. & & 0.730 & 0.813 & 0.251 & 2.635 & 29 & 9 & 69 & N.R. & & 0.529 & 0.742 & 0.293 & 1.877 \\
\hline Trend & & & & & & 0.974 & 1.017 & 0.370 & 2.798 & & & & & & 0.593 & 0.802 & 0.356 & 1.803 \\
\hline \multicolumn{19}{|l|}{ rs2910164 } \\
\hline $\mathrm{CC}$ & 23 & 13 & 43 & 19.25 & .015 & & Ref. & & & 35 & 12 & 66 & N.R. & .426 & & Ref. & & \\
\hline CG & 14 & 2 & 86 & N.R. & & 0.013 & 0.139 & 0.029 & 0.659 & 23 & 7 & 70 & N.R. & & 0.581 & 0.766 & 0.297 & 1.976 \\
\hline GG & 3 & 0 & 100 & N.R. & & 0.994 & NA & & & 10 & 3 & 70 & N.R. & & 0.452 & 0.609 & 0.167 & 2.219 \\
\hline $\mathrm{CG}+\mathrm{GG}$ & 17 & 2 & 88 & N.R. & & 0.003 & 0.089 & 0.018 & 0.443 & 33 & 10 & 70 & N.R. & & 0.431 & 0.711 & 0.304 & 1.660 \\
\hline Trend & & & & & & 0.004 & 0.117 & 0.027 & 0.495 & & & & & & 0.402 & 0.776 & 0.429 & 1.404 \\
\hline rs6505162 & & & & & & & & & & & & & & & & & & \\
\hline $\mathrm{CC}$ & 28 & 13 & 54 & 42.38 & .139 & & Ref. & & & 37 & 9 & 76 & N.R. & .177 & & Ref. & & \\
\hline $\mathrm{AC}$ & 9 & 2 & 78 & N.R. & & 0.301 & 0.421 & 0.082 & 2.166 & 26 & 11 & 58 & 57.26 & & 0.199 & 1.849 & 0.724 & 4.723 \\
\hline $\mathrm{AA}$ & 2 & 0 & 100 & N.R. & & 0.993 & NA & & & 5 & 2 & 60 & 38.63 & & 0.554 & 1.625 & 0.325 & 8.116 \\
\hline $\mathrm{AC}+\mathrm{AA}$ & 11 & 2 & 82 & N.R. & & 0.177 & 0.321 & 0.061 & 1.674 & 31 & 13 & 58 & 40.24 & & 0.195 & 1.806 & 0.739 & 4.416 \\
\hline Trend & & & & & & 0.144 & 0.333 & 0.076 & 1.458 & & & & & & 0.257 & 1.454 & 0.761 & 2.776 \\
\hline \multicolumn{19}{|l|}{ rs7372209 } \\
\hline $\mathrm{CC}$ & 24 & 8 & 67 & N.R. & .356 & & Ref. & & & 38 & 12 & 68 & N.R. & .723 & & Ref. & & \\
\hline $\mathrm{CT}$ & 13 & 5 & 62 & 42.38 & & 0.942 & 0.956 & 0.280 & 3.265 & 26 & 9 & 65 & N.R. & & 0.982 & 1.011 & 0.402 & 2.540 \\
\hline $\mathrm{TT}$ & 3 & 2 & 33 & 18.27 & & 0.177 & 3.721 & 0.552 & 25.103 & 4 & 1 & 75 & N.R. & & 0.321 & 0.351 & 0.044 & 2.782 \\
\hline $\mathrm{CT}+\mathrm{TT}$ & 16 & 7 & 56 & 42.38 & & 0.732 & 1.216 & 0.397 & 3.725 & 30 & 10 & 67 & N.R. & & 0.700 & 0.839 & 0.344 & 2.045 \\
\hline Trend & & & & & & 0.398 & 1.474 & 0.600 & 3.621 & & & & & & 0.440 & 0.764 & 0.386 & 1.513 \\
\hline
\end{tabular}


Micrometastasis $(n=40)$

Overt nodal metatstasis $(\mathrm{n}=68)$

$$
\text { Log-rank }
$$

No RFS Median trend test, Prob

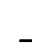

Letian

Log-rank

rend test

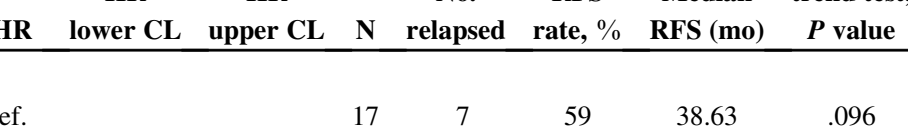

Prob

HR

HR rs11614913

$\begin{array}{lll}\text { TT } & 11 \quad 6\end{array}$

$\begin{array}{lll}\text { CT } & 15 & 4\end{array}$

$73 \quad \mathrm{~N}$

$5-64$

$\begin{array}{lllll}\mathrm{CT}+\mathrm{CC} & 29 & 5 & 64 & \mathrm{~N} . \mathrm{N} .\end{array}$

是

Trend

$\begin{array}{lll}0.184 & 0.349 & 0.074\end{array}$

$\begin{array}{lll}\mathbf{0 . 0 3 2} & \mathbf{0 . 1 6 6} & \mathbf{0 . 0 3 2}\end{array}$

$\begin{array}{lll}0.050 & 0.238 & 0.057\end{array}$

$\begin{array}{llll}0.035 & 0.410 & 0.180\end{array}$

$\begin{array}{lrrll} & 17 & 7 & 59 & 38.63 \\ 1.651 & 37 & 14 & 62 & 57.26 \\ \mathbf{0 . 8 5 9} & 12 & 1 & 92 & \text { N.R. } \\ 1.002 & 49 & 15 & 69 & \text { N.R. }\end{array}$

0.938

N.R.

.096

\begin{tabular}{llll} 
& Ref. & & \\
0.549 & 0.743 & 0.281 & 1.964 \\
0.088 & 0.158 & 0.019 & 1.312 \\
0.269 & 0.583 & 0.224 & 1.519 \\
0.075 & 0.525 & 0.258 & 1.066 \\
\hline
\end{tabular}

